\title{
Identification and partial characterisation of metalloproteases secreted by a Mesanophrys-like ciliate parasite of the Norway lobster Nephrops norvegicus
}

\author{
H. J. Small ${ }^{1,3, *}$, D. M. Neil ${ }^{1}$, A. C. Taylor $^{1}$, G. H. Coombs ${ }^{2}$ \\ ${ }^{1}$ Division of Environmental and Evolutionary Biology, and ${ }^{2}$ Division of Infection and Immunity, \\ Institute of Biomedical \& Life Sciences, University of Glasgow, Glasgow G12 8QQ, UK
}

${ }^{3}$ Present address: Virginia Institute of Marine Science, College of William and Mary, Gloucester Point, Virginia 23062, USA

\begin{abstract}
A ciliate parasite, tentatively identified as Mesanophrys sp. of Norway lobsters Nephrops norvegicus, is demonstrated to secrete several proteases into the culture medium (modified Nephrops saline). Analyses using substrate-impregnated sodium dodecylsulfate-polyacrylamide gel electrophoresis (SDS-PAGE) revealed 12 activity bands differing greatly in mobility in the gels. The complete inhibition of proteolytic activity by 1,10-phenanthroline indicated that the proteases are of the metallo class. The proteases were active at the physiological temperature $\left(8^{\circ} \mathrm{C}\right)$ and haemolymph $\mathrm{pH}$ (7.8) of the host. The proteases were selective in the degradation of several host proteins, including the myosin heavy chain, which is a major structural component of lobster muscle. Consequently, these proteases may have important roles in several aspects of the host-parasite interaction including invasion, nutrient uptake by the ciliate, and pathogenesis.
\end{abstract}

KEY WORDS: Ciliate $\cdot$ Parasite $\cdot$ Proteases $\cdot$ Secreted $\cdot$ Pathology

\section{INTRODUCTION}

Histophagous ciliates of the genus Mesanophrys have previously been described parasitising several crustaceans, including the shore crab Carcinus maenas (Cattaneo 1888), the edible crab Cancer pagurus (Grolièr \& Leglise 1977), the Dungeness crab C. magister (Morado \& Small 1994) and the blue crab Callinectes sapidus (Messick \& Small 1996). We recently discovered a histophagous ciliate infecting Norway lobsters Nephrops norvegicus from the Clyde Sea area in Scotland that appears to belong to the genus Mesanophrys by morphological feature comparison (Small et al. 2005).

The invasion of these histophagous ciliates into their crustacean host is poorly understood. Morado et al. (1999) suggested that Mesanophrys pugettensis enters the Dungeness crab via lesions in the epidermal surface associated with the moult cycle; inside they spread through the body and multiply to high densities in tis- sues and haemolymph. Hibbits \& Sparks (1983) also suggested that the cuticle of the isopod Gnorimosphaeroma oregonensis is the location of initial ciliate invasion. In several other parasitic infections, proteases released by the pathogen have been shown to play various roles in the establishment and progression of disease. For example, some parasite proteases degrade host extracellular matrix proteins, thus facilitating spread of the parasite within host tissues (Schulte \& Scholze 1989). Many marine bacterial, fungal and protozoan pathogens secrete proteases during in vitro culture, suggesting that protease release could be important in pathogenesis. Examples include the salmon pathogen Aeromonas salmonicida (Rockey et al. 1988), the crayfish pathogen Aphanomyces astaci (Söderhäll \& Unestam 1975), and the oyster parasite Perkinsus marinus (La Peyre \& Faisal 1995, La Peyre et al. 1995). Uronema marinum, a histophagous parasitic ciliate of the olive flounder Paralichthys olivaceus, has also been reported to secrete proteases during in vitro culture 
(Lee et al. 2003); in this case, secreted proteases may be directly responsible for many of the clinical symptoms associated with the disease, such as tissue necrosis.

Several reports of Mesanophrys spp. infections in crustaceans have indicated that these ciliates infiltrate and consume host tissues and haemocytes (Poisson 1930, Bang et al. 1972, Messick \& Small 1996). The discovery of a Mesanophrys-like parasitic ciliate infecting Norway lobsters Nephrops norvegicus, and isolation of the ciliate via in vitro cultivation, has allowed proteolytic factors that may play a role in the parasite's establishment and proliferation to be investigated. This paper reports on the characterisation of these proteases, and suggests ways in which they may be involved in the pathogenesis of ciliate disease in lobsters.

\section{MATERIALS AND METHODS}

Isolation and cultivation of the ciliate parasite. Routine screening of Nephros norvegicus from the Clyde Sea area for the parasitic dinoflagellate Hematodinium $\mathrm{sp}$. led to the discovery and identification of a ciliate infection in several Norway lobsters (Small et al. 2005). Haemolymph samples were withdrawn aseptically from the base of the fifth pereiopod using a $1 \mathrm{ml}$ disposable syringe and 25-gauge needle following sterilisation of the cuticle with $70 \%(\mathrm{v} / \mathrm{v})$ ethanol. Ciliate infections were diagnosed by viewing haemolymph smears using light microscopy. Parasitic ciliates were isolated in $3.5 \mathrm{~cm}$ well plates with $0.2 \mathrm{ml}$ infected haemolymph added to $5 \mathrm{ml}$ culture medium in each well. The culture medium comprised $10 \%(\mathrm{v} / \mathrm{v})$ heat-inactivated foetal calf serum (FCS) in autoclaved balanced Nephrops saline (Appleton \& Vickerman 1998), containing $\mathrm{NaCl}_{\text {, }}$ $27.99 \mathrm{~g} \mathrm{l}^{-1} ; \mathrm{KCl} 0.95 \mathrm{~g} \mathrm{l}^{-1} ; \mathrm{CaCl}_{2} 2.014 \mathrm{~g} \mathrm{l}^{-1} ; \mathrm{MgSO}_{4}$ $2.465 \mathrm{~g} \mathrm{l}^{-1} ; \mathrm{Na}_{2} \mathrm{SO}_{4} 0.554 \mathrm{~g} \mathrm{l}^{-1}$; HEPES $1.92 \mathrm{~g} \mathrm{l}^{-1}$, adjusted to $\mathrm{pH} 7.8$. Penicillin $\mathrm{G}\left(10 \mathrm{U} \mathrm{ml}^{-1}\right)$ and streptomycin $\left(10 \mu \mathrm{g} \mathrm{ml}^{-1}\right)$ were added to inhibit bacterial contamination. The medium was filter-sterilised $(0.2 \mu \mathrm{m})$ after the addition of all constituents. Cultures were incubated at $8^{\circ} \mathrm{C}$. Serial subculturing gave rise to axenic cultures.

Experimental subcultures for protease analyses were initiated with the addition of $1 \times 10^{5}$ ciliates to $5 \mathrm{ml}$ culture medium in $3.5 \mathrm{~cm}$ well plates, in quadruplicate, and were maintained at $8^{\circ} \mathrm{C}$. Cultures were checked by light microscopy daily for bacterial contamination. On Days 3 and 7, a $50 \mu \mathrm{l}$ sample of the ciliate suspension was removed and added to $10 \mu \mathrm{l}$ of phosphatebuffered saline (PBS) containing $20 \mu \mathrm{g} \mathrm{ml}^{-1} 4^{\prime} 6$ diamidino-2-phenylindole (DAPI, Sigma). We placed $20 \mu \mathrm{l}$ of this suspension on a glass slide and covered it with a coverslip. The ciliate nuclei were observed under oil immersion using fluorescence microscopy
(Zeiss Axioplan 2 at an excitation wavelength of $350 \mathrm{~nm}$ ). No fluorescent signal from contaminating protists or bacteria was detectable. Cell viability was assessed by viewing cultures under phase contrast microscopy. The total volume of medium in each well was collected on Days 1, 3, 5 and 7. The samples were centrifuged at $400 \times g$ for $10 \mathrm{~min}$ at $4{ }^{\circ} \mathrm{C}$, and $4.9 \mathrm{ml}$ culture medium was collected, passed through a $0.2 \mu \mathrm{m}$ filter and frozen at $-80^{\circ} \mathrm{C}$ until analysed. The cell pellet was resuspended in $100 \mu \mathrm{l}$ culture medium and $10 \mu \mathrm{l}$ of this was mixed with $10 \mu \mathrm{l} 1 \%$ (v/v) formaldehyde (in PBS) to immobilise the ciliates. Ciliate densities were estimated using an Improved Neubauer counting chamber following standard procedures.

Preparation of ciliate lysates. Ciliates from an in vitro culture were collected, and cell density was estimated as described above. The resulting ciliate suspension $\left(5 \times 10^{4}\right.$ cells $\left.100 \mathrm{\mu l}^{-1}\right)$ was washed and centrifuged $\left(400 \times g\right.$ for $10 \mathrm{~min}$ at $\left.4^{\circ} \mathrm{C}\right) 3$ times with Nephrops saline before resuspension in $100 \mu \mathrm{l}$ Nephrops saline. Cell lysates were prepared by freezing and thawing the sample 3 times, followed by centrifugation $(10000 \times g$ for $10 \mathrm{~min})$ at $4^{\circ} \mathrm{C}$. The supernatant fraction of the cell lysate was carefully removed and stored at $-80^{\circ} \mathrm{C}$ until analysed.

Spectrophotometric assay for protease activity. Protease activities in ciliate culture medium samples were assayed following the method of Sarath et al. (1989). Azocasein substrate $(3 \% \mathrm{w} / \mathrm{v})$ was prepared by dissolving azocasein (Sigma) in $0.1 \mathrm{M}$ Tris- $\mathrm{HCl}, \mathrm{pH}$ 8.0, followed by centrifugation at $10000 \times g$ for $10 \mathrm{~min}$ at $4^{\circ} \mathrm{C}$. The supernatant (substrate) was removed and stored on ice prior to use. The assay was initiated by the addition of $75 \mu \mathrm{l}$ of ciliate culture medium sample to $125 \mu \mathrm{l}$ substrate solution. Samples were incubated for $18 \mathrm{~h}$ at $37^{\circ} \mathrm{C}$. The reaction was terminated by the addition of $600 \mu$ licecold $10 \%(\mathrm{w} / \mathrm{v})$ trichloroacetic acid (TCA), after which the mixtures were kept at $4^{\circ} \mathrm{C}$ for $30 \mathrm{~min}$. The samples were centrifuged at $9000 \times g$ for 5 min to pellet the precipitated proteins (including undigested azocasein). Then $0.6 \mathrm{ml}$ of the supernatant was removed and mixed with $0.7 \mathrm{ml} 1.0 \mathrm{M} \mathrm{NaOH}$, and the absorbance of the mixture read at $440 \mathrm{~nm}$ on a spectrophotometer. We defined $1 \mathrm{U}$ of protease activity as the enzyme activity resulting in an absorbance of 1.0 in a $1 \mathrm{~cm}$ cuvette, under the conditions of the assay. Controls comprised cell culture media without the addition of ciliates. Each sample was assayed in triplicate.

Substrate-impregnated SDS-PAGE. The proteases in the ciliate culture medium and in ciliate lysates were separated using gelatin-impregnated polyacrylamide gel electrophoresis according to the method of La Peyre et al. (1995), with minor modifications. Gelatin was added to the $8 \%(\mathrm{w} / \mathrm{v})$ acrylamide resolving gel at a final concentration of $0.2 \%$ protein $(\mathrm{w} / \mathrm{v})$. Ciliate cul- 
ture medium/lysate samples $(5 \mu \mathrm{l})$ were mixed with $15 \mu \mathrm{l}$ of electrophoresis sample buffer (62.5 mM Tris$\mathrm{HCl}, \mathrm{pH} 6.8$, containing SDS $(2 \% \mathrm{w} / \mathrm{v}), \beta$-mercaptoethanol $(5 \% \mathrm{w} / \mathrm{v})$, glycerol $(10 \% \mathrm{w} / \mathrm{v})$ and $0.004 \%$ pyronin $\mathrm{Y}$ ) before loading onto gels containing copolymerised gelatin. Electrophoresis was performed using a BioRad mini-Protean system at $30 \mathrm{~mA}$ constant current, containing the Tris-glycine buffer for $90 \mathrm{~min}$ at $4^{\circ} \mathrm{C}$. After electrophoresis, the resolved gels were incubated with agitation in Triton X-100 (2.5\% v/v in distilled $\mathrm{H}_{2} \mathrm{O}$ ) for $30 \mathrm{~min}$ at $4{ }^{\circ} \mathrm{C}$ to remove SDS and reactivate the resolved proteases. To detect proteolytic activity, the gels were incubated in $0.1 \mathrm{M}$ Tris- $\mathrm{HCl}$, $\mathrm{pH} 8.0$, for 4 to $12 \mathrm{~h}$ at $37^{\circ} \mathrm{C}$. The gels were fixed and stained with Coomassie blue, then destained until clear bands were apparent where hydrolysis of embedded substrate had occurred. Apparent molecular masses of the proteases were determined from their mobility relative to known protein standards, although these were used only as means of identifying individual bands. Proteins did not migrate according to their molecular masses under the conditions used.

Effect of inhibitors on protease activity. Stock solutions of phenylmethylsulphonyl fluoride (PMSF, $200 \mathrm{mM})$, Pepstatin A (1 mM), and 1,10-phenanthroline (200 mM) were prepared in $100 \%$ methanol. A stock solution of N-(N-(L-3-trans-carboxirane-2-carbonyl)-Lleucyl)-agmatine (E-64, $10 \mathrm{mM}$ ) was prepared in 100\% ethanol. Stock solutions of leupeptin (10 mM) and ethylenediaminetetraacetic acid (EDTA, $500 \mathrm{mM}$ ) were prepared in $0.1 \mathrm{M}$ Tris- $\mathrm{HCl}, \mathrm{pH}$ 8.0. Stock solutions of all the inhibitors were diluted in $0.1 \mathrm{M}$ Tris- $\mathrm{HCl}, \mathrm{pH} 8.0$, to the appropriate working concentration (see list in Table 1). Ciliate culture medium samples with the maximum protease activity (after $7 \mathrm{~d}$ culture) were used in the inhibitor studies. To quantify the effects of the inhibitors, each of the appropriately diluted inhibitors was incubated for $1 \mathrm{~h}$ at $37^{\circ} \mathrm{C}$ with $100 \mu \mathrm{l}$ of ciliate culture medium. To these, $125 \mu \mathrm{l}$ of azocasein substrate solution was then added, and the samples were incubated for $18 \mathrm{~h}$ at $37^{\circ} \mathrm{C}$. The proteolytic activity was measured spectrophotometrically as described in the foregoing subsection. The samples were compared with assays run in the absence of inhibitors. The effect of each inhibitor was assayed in triplicate.

To investigate the possible differences in inhibitor susceptibility between proteolytic bands, ciliate culture medium samples were resolved by gelatin-SDSPAGE as in the foregoing subsection with minor alterations. The supernatant-sample buffer mixture was loaded across all wells of the gelatin-SDS-PAGE minigel. After electrophoresis and Triton X-100 treatment, the gel was sectioned into six $1.5 \mathrm{~cm}$ vertical strips, and the strips were incubated individually in $5 \mathrm{ml}$ of $0.1 \mathrm{M}$ Tris-HCl, pH 8.0, containing the appropriate inhibitor for $6 \mathrm{~h}$ at $37^{\circ} \mathrm{C}$. The gels were fixed and stained with Coomassie blue, then destained (inhibitor concentrations are detailed in Table 1).

Effect of temperature and $\mathbf{p H}$ on protease activity. The effect of temperature on protease activity in ciliate cell culture medium samples was examined spectrophotometrically as described above. The substratesample mixtures were incubated at 8,25 and $37^{\circ} \mathrm{C}$ for $18 \mathrm{~h}$. At each temperature, samples were assayed in triplicate.

The effect of $\mathrm{pH}$ on protease activity in ciliate culture medium samples was examined spectrophotometrically and by gelatin-SDS-PAGE. For the spectrophotometric assay, azocasein substrate (3\% w/v) was dissolved in $0.1 \mathrm{M}$ Tris- $\mathrm{HCl} \mathrm{pH} 7.0$, followed by centrifugation at $10000 \times g$ for $10 \mathrm{~min}$ at $4{ }^{\circ} \mathrm{C}$. The supernatant was removed and the $\mathrm{pH}$ increased by the addition of $10 \mathrm{M} \mathrm{NaOH}$. Samples of substrate at $\mathrm{pH} 7.0$ and 8.0 were removed and stored on ice prior to use. Ciliate culture medium samples $(75 \mu \mathrm{l})$ were mixed with $125 \mu \mathrm{l}$ substrate solution at the different $\mathrm{pH}$ values, and incubated for $18 \mathrm{~h}$ at $37^{\circ} \mathrm{C}$. Protease activity was measured as described earlier. Controls comprised culture media without the addition of ciliates. Each substrate sample was assayed in triplicate. Ciliate culture medium samples were subjected to gelatinSDS-PAGE, and washed in Triton X-100 as described earlier. Each gel was sectioned into respective sample lanes and incubated individually in $5 \mathrm{ml}$ of $0.1 \mathrm{M}$ Tris- $\mathrm{HCl}$ at $\mathrm{pH} 7.0$ and 8.0 for $6 \mathrm{~h}$ at $37^{\circ} \mathrm{C}$. The gels were then stained and destained.

Effect of proteases on host muscle proteins. The effect of proteases present in ciliate culture medium on host tissue proteins was investigated using a sample of abdominal flexor muscle from the Norway lobster. Briefly, $100 \mathrm{mg}$ of abdominal flexor muscle was homogenised in $500 \mu \mathrm{l} 0.1 \mathrm{M}$ Tris- $\mathrm{HCl}, \mathrm{pH} 8.0$, followed by centrifugation at $3000 \times g$ for $10 \mathrm{~min}$ at $4^{\circ} \mathrm{C}$. The muscle protein supernatant was removed and placed on ice prior to use. Samples of protein supernatant $(20 \mu \mathrm{l})$ were mixed with $20 \mu \mathrm{l}$ ciliate culture medium (Day 7) and $20 \mu \mathrm{l} 0.1 \mathrm{M}$ Tris- $\mathrm{HCl} \mathrm{pH}$ 8.0. Reaction mixtures were incubated at $8^{\circ} \mathrm{C}$ for $15 \mathrm{~h}$. Controls included the incubation of $20 \mu \mathrm{l}$ of $0.1 \mathrm{M}$ Tris- $\mathrm{HCl} \mathrm{pH} 8.0$ with equal volumes of protein supernatant, ciliate culture medium, and uninoculated culture medium under the same conditions. Protein degradation was evaluated by standard SDS-PAGE (Sambrook et al. 1989).

\section{RESULTS}

\section{Protease activity and ciliate growth in vitro}

Ciliate density increased approximately 10-fold over $7 \mathrm{~d}$ in culture. Ciliates were always observed to be 
motile when cultures were examined daily using phase contrast microscopy. Protease activity in samples of culture medium was detected as early as $1 \mathrm{~d}$ postinoculation, and increased over Days 3,5 and 7. This increase in activity correlated closely with the increase in ciliate density (Fig. 1). No proteolytic activity could be detected in uninoculated culture medium.

\section{Detection of proteases in ciliate culture medium and lysates by gelatin-SDS-PAGE}

The presence of multiple protease activities in ciliate culture medium and lysate samples was confirmed using gelatin-SDS-PAGE. We detected 12 zones of hydrolysis with apparent molecular masses ranging from 20 to $220 \mathrm{kDa}$ in the samples of culture medium, while only 8 of the zones of hydrolysis were clearly evident in lysate samples (Fig. 2). The profile of protease activities in the ciliate lysate differed from that in the medium not only in a reduction in the number of bands of gelatin hydrolysis (notably the absence of the $50 \mathrm{kDa}$ band, Band 7, observed in the samples of ciliate culture medium), but also in the relative intensity of gelatin digestion of the various bands. The low molecular mass bands (20 to $50 \mathrm{kDa}$ ) appeared faint, while the high molecular mass bands ( 70 to $220 \mathrm{kDa}$ ) were very intense.

\section{Effect of inhibitors on proteases present in ciliate culture medium}

Pre-incubation of samples of the ciliate culture medium with protease inhibitors before determining the proteolytic activity by the spectrophotometric assay revealed marked inhibition of proteolytic activity when samples were incubated in the presence of $10 \mathrm{mM}$ 1,10-phenanthroline (only $2.5 \pm 8.8 \%$ activity remained) (Table 1). Partial inhibition was observed with the addi-

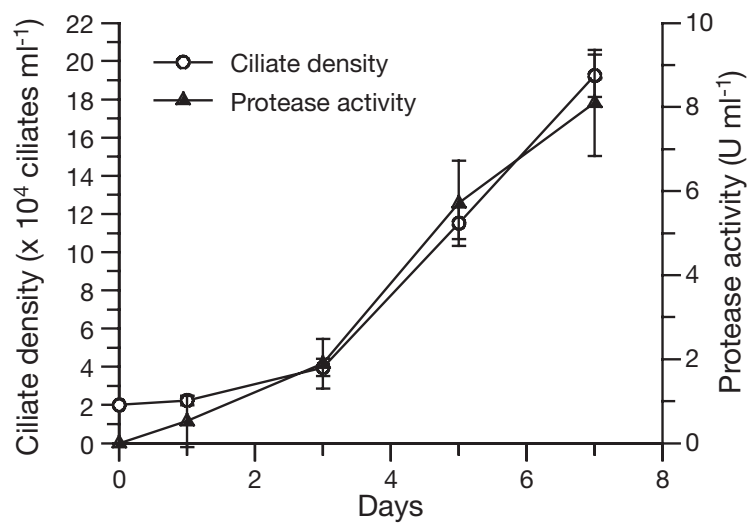

Fig. 1. Changes in ciliate density and protease activity in cultures over $7 \mathrm{~d}$. Mean $\pm \mathrm{SD}, \mathrm{n}=3$

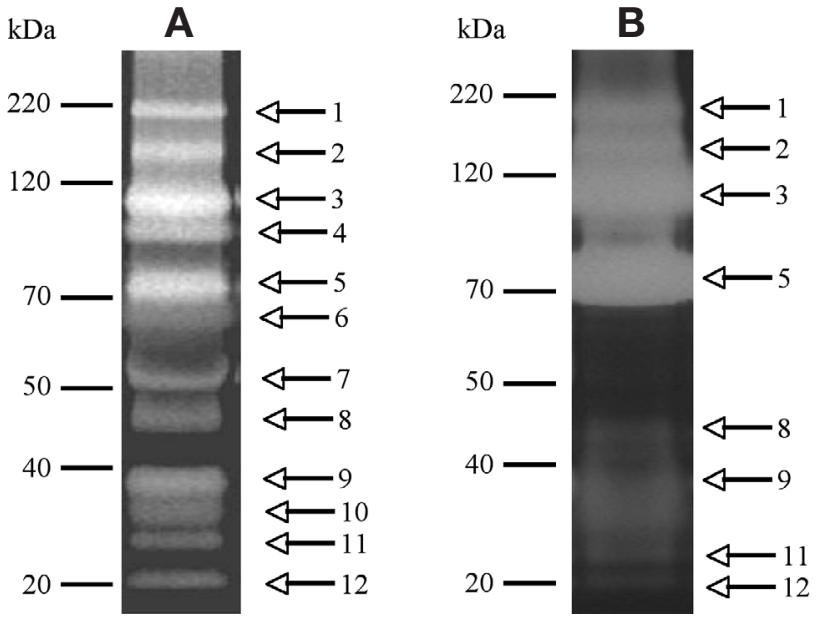

Fig. 2. Detection of proteases in (A) ciliate culture medium, and (B) ciliate crude lysates by gelatin-SDS-PAGE. Positions of molecular mass standards are indicated on the left; arrows indicate zones of hydrolysis

tion of EDTA $(42.9 \pm 3.3 \%$ activity remained with $10 \mathrm{mM}$ EDTA). However, addition of the inhibitors PMSF, Pepstatin A, E-64 and leupeptin had no effect on the proteolytic activity of samples of ciliate culture medium. The activities of all proteases separated by gelatinSDS-PAGE were completely inhibited when the postelectrophoresis activation buffer contained $10 \mathrm{mM}$ 1,10-phenanthroline (Table 1). The inclusion of $10 \mathrm{mM}$ EDTA in the incubation buffer inhibited the majority of proteases apart from the 3 largest proteases, which were partially inhibited in apparent activity. Addition of the inhibitors PMSF, Pepstatin A, E-64 and leupeptin did not detectably inhibit hydrolysis of gelatin.

\section{Effect of temperature and $\mathrm{pH}$ on protease activity in ciliate culture medium}

To investigate the effect of temperature on enzyme activity, protease activity in samples of ciliate culture medium was assayed by the spectrophotometric assay at different temperatures. Protease activity could be detected at $8^{\circ} \mathrm{C}\left(2.2 \pm 0.5 \mathrm{U} \mathrm{ml}^{-1}\right)$, and increased 2.9fold to $6.2 \pm 0.3$ at $25^{\circ} \mathrm{C}$, and 4.5 -fold to $9.8 \pm 0.2 \mathrm{U} \mathrm{ml}^{-1}$ when the assay was performed at $37^{\circ} \mathrm{C}$. Spectrophotometric measurements of protease activity indicated that the hydrolysis of azocasein was highest at $\mathrm{pH} 8.0$ $\left(7.4 \pm 0.2 \mathrm{U} \mathrm{ml}^{-1}\right)$ with $0.1 \mathrm{M}$ Tris- $\mathrm{HCl}$ as the buffer. Decreasing the $\mathrm{pH}$ to 7.0 resulted in a reduction of protease activity $\left(6.5 \pm 0.2 \mathrm{U} \mathrm{ml}^{-1}\right)$. Gelatin-SDS-PAGE analysis of the ciliate culture medium samples revealed 12 distinct zones of hydrolysis both at $\mathrm{pH} 7.0$ and 8.0 (data not shown). However, the hydrolysis was more intense at $\mathrm{pH}$ 8.0. 
Table 1. Effect of inhibitors on activity of proteases present in ciliate culture medium. $100 \%$ activity was $7.08 \pm 0.33 \mathrm{U} \mathrm{ml}^{-1}$ (mean $\pm \mathrm{SD}, \mathrm{n}=3$ )

\begin{tabular}{|c|c|c|c|}
\hline Inhibitor & Conc. & $\begin{array}{l}\text { Protease } \\
\text { activity } \\
\text { (\% control) }\end{array}$ & $\begin{array}{c}\text { Inhibition of } \\
\text { gelatin-SDS-PAGE } \\
\text { digestion }\end{array}$ \\
\hline Control (0.1 M Tris-HCl) pH 8.0 & & $100 \pm 4.6$ & None \\
\hline Control (ethanol) & & $94.5 \pm 6.1$ & None \\
\hline Control (methanol) & & $95.9 \pm 2.9$ & None \\
\hline \multicolumn{4}{|c|}{ Serine protease/cysteine protease inhibitors: } \\
\hline \multirow[t]{2}{*}{ PMSF } & $1 \mathrm{mM}$ & $94.6 \pm 2.4$ & \\
\hline & $10 \mathrm{mM}$ & $92.0 \pm 2.8$ & None \\
\hline \multirow[t]{2}{*}{ Leupeptin } & $1 \mu \mathrm{M}$ & $94.4 \pm 2.9$ & \\
\hline & $10 \mu \mathrm{M}$ & $91.1 \pm 3.7$ & None \\
\hline \multicolumn{4}{|l|}{ Cysteine protease inhibitor: } \\
\hline E-64 & $\begin{array}{r}1 \mu \mathrm{M} \\
10 \mu \mathrm{M}\end{array}$ & $\begin{array}{l}97.5 \pm 5.2 \\
94.2 \pm 2.5\end{array}$ & None \\
\hline \multicolumn{4}{|l|}{ Aspartic protease inhibitor: } \\
\hline Pepstatin A & $1 \mu \mathrm{M}$ & $92.5 \pm 4.4$ & None \\
\hline \multicolumn{4}{|l|}{ Metallo-protease inhibitors: } \\
\hline 1,10 phenanthroline & $\begin{array}{r}1 \mathrm{mM} \\
10 \mathrm{mM}\end{array}$ & $\begin{array}{r}41.4 \pm 3.8 \\
2.5 \pm 8.8\end{array}$ & Complete \\
\hline \multirow[t]{2}{*}{ EDTA } & $1 \mathrm{mM}$ & $87.0 \pm 3.6$ & \\
\hline & $10 \mathrm{mM}$ & $42.9 \pm 3.3$ & Partial \\
\hline
\end{tabular}

\section{Host protein degradation by proteases present in ciliate culture medium}

The multiple proteases present in samples of the ciliate culture medium had a selective effect on several abdominal flexor muscle proteins (Lane C, Fig. 3). In particular, the myosin heavy chain and one of the Troponin I family of proteins were completely degraded. There was also degradation of several unidentified muscle proteins with masses in the range of 100 to $120 \mathrm{kDa}$. However, paramyosin, actin and other muscle proteins remained unaffected. The FCS protein component of the culture medium occurred in smaller amounts in samples of ciliate culture medium (Lane D, Fig. 3) compared with the uninoculated control culture medium (Lane E, Fig. 3).

\section{DISCUSSION}

Proteolytic enzymes from parasites are thought to be involved in parasite nutrition, anticoagulation and evasion of the host immune system (McKerrow 1989). They are also believed to play key roles in the processes of penetration and migration of parasites through host tissues (Klemba \& Goldberg 2002). The extensive tissue infiltration and damage observed during Mesanophrys spp. infections in crustaceans (Armstrong et al. 1981, Sparks et al. 1982, Hibbits \& Sparks 1983, Messick \& Small 1996) indicates a likely role for proteases in such processes.
The results of this study show that the Mesanophrys-like ciliate multiplied during in vitro culture, with density increasing 10-fold over the $7 \mathrm{~d}$ period of the incubations. Comparable increases in ciliate numbers occurred in experimental infections of Cancer pagurus and C. magister with Mesanophrys sp. (Bang et al. 1972, Cain \& Morado 2001). Densities of the scuticociliate fish pathogen Philasterides dicentrarchi have also been observed to multiply 5 -fold over $7 \mathrm{~d}$ (reaching a plateau phase after $3 \mathrm{~d}$ ) during in vitro culture using a similar seeding density to that used in the present study (Inglesias et al. 2003).

Associated with the increase in growth of the ciliate in vitro, was the release of multiple extracellular proteases. As the ciliates were apparently always motile, and were still increasing in number when the experiment was terminated (Day 7), we concluded that the extracellular proteases detected in the culture medium had been actively secreted. The relatively close correlation between the amount of secreted proteases and number of ciliates (Fig. 1) suggests that the secreted proteases did not accumulate in the medium, or at least not in active forms.

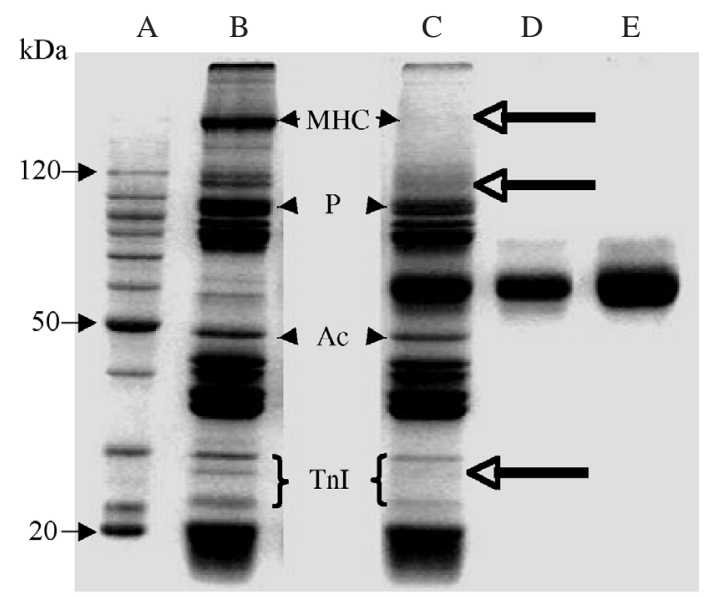

Fig. 3. Digestion of deep abdominal flexor (DAF) muscle proteins by proteases present in ciliate culture medium; sizes are indicated on the left. Lane A: molecular mass standards; Lane B: DAF protein sample incubated in absence of ciliate culture medium; Lane C: DAF protein sample incubated in presence of ciliate culture medium; Lane D: ciliate culture medium sample; Lane E: uninoculated (control) culture medium sample. Note degradation of DAF muscle proteins in Lane C (arrows), and also reduced intensity of FCS proteins in ciliate culture medium sample (Lane D) compared to control medium sample (Lane E). MHC: myosin heavy chain; P: paramyosin; Ac: actin; TnI: Troponin I family 
Inhibitory studies using both spectrophotometry and substrate-impregnated SDS-PAGE methods (Table 1) indicated that the proteases secreted by the ciliate are of the metallo class, with complete and partial inhibition of activity being observed using the inhibitors 1,10-phenanthroline and EDTA, respectively. Metalloproteases produced by several protozoan parasites are suggested to contribute to the invasion and degradation of host tissues (McKerrow et al. 1993), and are important in the pathogenesis of parasitic infections. Metalloproteases have been documented from several marine pathogens during in vitro culture, including the piscine haemoflagellate Cryptobia salmositica (Zuo \& Woo 1998), the bivalve pathogen Vibrio alginolyticus (Nottage \& Birkbeck 1987), and the fish pathogen Aeromonas salmonicida (Arnesen et al. 1995). In the scuticociliate parasite of fish Uronema marinum, Lee et al. (2003) detected metalloprotease secretion as early as $10 \mathrm{~min}$ in ciliate cell suspensions using fluorescence polarisation. They suggested that the metalloproteases are involved in the pathogenesis of this ciliate infection in fishes. Other ciliate species such as Tetrahymena pyriformis and T. thermophilia have previously been shown to contain and secrete proteases (Banno et al. 1983, Straus et al. 1992). In these studies, proteases were suggested to be involved in both intracellular and extracellular digestion. In addition, lysosomal-released enzymes from $T$. thermophilia have been implicated in the process of extracellular digestion and parasite nutrition, with proteolytic enzymes facilitating the release of host particulate and soluble nutrients (Florin-Christensen et al. 1985, Tiedtke \& Rasmussen 1988). Thus, the proteases released by the present ciliate under investigation may also play a similar role in nutrient uptake, both in vitro and in vivo.

During ciliate infections of other crustaceans, extensive host tissue penetration and destruction are common observations (Armstrong et al. 1981, Sparks et al. 1982, Hibbits \& Sparks 1983, Messick \& Small 1996, Athanassopoulou et al. 2004). The present study has shown that proteases present in the ciliate culture medium selectively degrade the myosin heavy chain and one of the Troponin I family of proteins from Nephrops norvegicus abdominal flexor muscle in vitro (Fig. 3). Several unidentified muscle proteins with masses in the range of 100 to $120 \mathrm{kDa}$ were also degraded, but the paramyosin, actin and other muscle proteins remained unaffected by the proteases. The myosin heavy chain proteins are present in all muscle groups within the Norway lobster, and it seems likely that the same proteases secreted by the ciliate in vivo will degrade tissues containing these muscle groups and so be mediators of extensive tissue penetra- tion and digestion. Similarly, the multiple proteases secreted by the apicomplexan parasite Perkinsus marinus appear to degrade the gut epithelium and basement membranes of its host, the eastern oyster Crassostrea virginica, assisting parasitic invasion and spread through the oyster tissues (La Peyre et al. 1996).

In addition to tissue penetration/digestion, haemocytopenia is also a classic sign of advanced ciliate infections in crustaceans (Cattaneo 1888, Armstrong et al. 1981, Sparks et al. 1982, Cain \& Morado 2001). The Norway lobsters that were infected with the ciliate under study also had very few haemocytes present in the haemolymph samples taken to initiate in vitro cultures (H. J. Small pers. obs.). Released proteins, including proteases, can modulate the immune system of a pathogen's host. For example, the $64 \mathrm{kDa}$ protease and extracellular proteins secreted by Aeromonas salmonicida, which suppress the humoral immune response of Atlantic salmon Salmo salar, result in leucopenia and allow the bacteria to spread via the circulatory system and invade other tissues (Ellis et al. 1981, Hussain et al. 2000). Released proteins from $A$. salmonicida are also reported to induce degranulation of eosinophilic granular cells, releasing vasoactive compounds leading to acute shock in Atlantic salmon (Ellis et al. 1981). Similarly, the pathogenic haemoflagellate Cryptobia salmositica secretes a metalloprotease which can directly lyse fish erythrocytes causing anaemia (Zuo \& Woo 2000), while the proteases secreted by the apicomplexan oyster parasite Perkinsus marinus compromise the oyster's host defence mechanisms by inhibiting haemocyte motility and degrading plasma lysozyme and haemagglutinins (Garreis et al. 1996). Therefore, the reduction in circulating haemocytes during ciliate infections of crustaceans, previously attributed to consumption (Bang et al. 1972, Armstrong et al. 1981, Messick \& Small 1996), may also be due in part to the effect of secreted proteases.

In conclusion, the histophagous ciliate under study, thought to be a species of the genus Mesanophrys, secreted several metalloproteases during in vitro culture. These may well be important in the invasion of host tissues by the ciliate and also in the parasite's nutrition in vivo. Thus these metalloproteases may be key virulence factors and responsible for the tissue pathologies observed in infected crustaceans. Further studies are required to ascertain the exact contribution of these enzymes to the host-parasite relationship.

Acknowledgements. H.J.S. received a Natural Environment Research Council Studentship (NER/S/A/2000/03368). Thanks to Dr. Jeffrey Shields, who critically read the manuscript. 


\section{LITERATURE CITED}

Appleton PL, Vickerman KV (1998) In vitro cultivation and development cycle in culture of a parasitic dinoflagellate (Hematodinium sp.) associated with mortality of the Norway lobster (Nephrops norvegicus) in British waters. Parasitology 116:115-130

Armstrong DA, Burreson EM, Sparks AK (1981) A ciliate infection (Paranophrys sp.) in laboratory-held Dungeness crabs, Cancer magister. J Invertebr Pathol 37:201-209

Arnesen JA, Eggset G, Jørgensen TO (1995) Partial purification and characterization of extracellular metalloproteases from Aeromonas salmonicida ssp. J Fish Dis 18:283-295

Athanassopoulou F, Speare D, Cawthorn RJ, MacMillan R, Despres B (2004) Pathology of Anophryoides haemophila (Scuticociliatida: Orchitophryidae), parasite of American lobster Homarus americanus kept under experimental conditions. Aquaculture 236:103-117

Bang FB, Audouin J, Leglise M (1972) Ciliate infection of the blood of the edible crab, Cancer pagurus, in holding tanks in Brittany, France. J Invertebr Pathol 20:226-227

Banno Y, Yano K, Nozawa Y (1983) Purification and characterisation of a secreted proteinase from Tetrahymena pyriformis. Eur J Biochem 132:563-568

Cain TA, Morado JF (2001) Changes in total hemocyte and differential counts in Dungeness crabs infected with Mesanophrys pugettensis, a marine facultative parasitic ciliate. J Aquat Anim Health 13:310-319

Cattaneo G (1888) Su di un infusorio ciliato, parasito del sangue del Carcinus maenas. Zool Anz 11:456-459

Ellis AE, Hastings TS, Munro ALS (1981) The role of Aeromonas salmonicida extracellular products in the pathology of furunculosis. J Fish Dis 4:41-51

Florin-Christensen J, Florin-Christensen M, Knudsen J, Rasmussen L (1985) Cytolytic activity released from Tetrahymena. J Protozool 32:657-660

Garreis KA, La Peyre JF, Faisal M (1996) The effects of Perkinsus marinus extracellular products and purified proteases on oyster defence parameters in vitro. Fish Shellfish Immunol 6:581-597

Grolièr CA, Leglise M (1977) Paranophrys carcini n. sp., cilié Philasterina récolté dans l'hémolymphe du crabe Cancer pagurus Linné. Protistologica 13:503-507

Hibbits J, Sparks AK (1983) Observations on the histopathology caused by a parasitic ciliate (Paranophrys sp.?) in the isopod Gnorimosphaeroma oregonensis. J Invertebr Pathol 41:51-56

Hussain I, Mackie C, Cox D, Alderson R, Birkbeck TH (2000) Suppression of the humoral immune response of Atlantic salmon, Salmo salar L. by the $64 \mathrm{kDa}$ serine protease of Aeromonas salmonicida. Fish Shellfish Immunol 10:359-373

Inglesias R, Paramá A, Alvarez MF, Leiro J, Aja C, Sanmartín ML (2003) In vitro growth requirements for the fish pathogen Philasterides dicentrarchi (Ciliophora, Scuticociliatida). Vet Parasitol 111:19-30

Klemba M, Goldberg DE (2002) Biological roles of proteases in parasitic protozoa. Annu Rev Biochem 71:275-305

La Peyre JF, Faisal M (1995) Perkinsus marinus produces extracellular proteolytic factors in vitro. Bull Assoc Fish Pathol 15:28-31

La Peyre JF, Schafhauser DY, Rizkalla EH, Faisal M (1995) Production of serine proteases by the oyster pathogen Perkinsus marinus (Apicomplexa) in vitro. J Eukaryot Microbiol 42:544-551

La Peyre JF, Yarnall HA, Faisal M (1996) Contribution of Perkinsus marinus extracellular products in the infection of Eastern oysters (Crassostrea virginica). J Invertebr
Pathol 68:312-313

Lee EH, Kim CS, Cho JB, Ahn KJ, Kim KH (2003) Measurement of protease activity of live Uronema marinum (Ciliata: Scuticociliatida) by fluorescence polarisation. Dis Aquat Org 54:85-88

McKerrow JH (1989) Parasite proteinases. Exp Parasitol 68: 111-115

McKerrow JH, Sun E, Rosenthal PJ, Bouvier J (1993) The proteases and pathogenicity of parasitic protozoa. Annu Rev Microbiol 47:821-853

Messick GA, Small EB (1996) Mesanophrys chesapeakensis n.sp., a histophagous ciliate in the blue crab, Callinectes sapidus, and associated histopathology. Invertebr Biol 115:1-12

Morado FJ, Small EB (1994) Morphology and stomatogenesis of Mesanophrys pugettensis n. sp. (Scuticociliatida: Orchitphryidae), a facultative parasitic ciliate of the Dungeness crab, Cancer magister (Crustacea: Decapoda). Trans Am Microsc Soc 113:343-364

Morado JF, Giesecke RH, Syrjala SE (1999) Molt related mortalities of the Dungeness crab Cancer magister caused by a marine facultative ciliate Mesanophrys pugettensis. Dis Aquat Org 38:143-150

Nottage AS, Birkbeck TH (1987) Purification of a proteinase produced by the bivalve pathogen Vibrio alginolyticus NCMB 1339. J Fish Dis 10:211-220

Poisson R (1930) Observations sur Anophrys sarcophaga Cohn (= A. maggii Cattaneo) infusoire holotriche marin et sur son parasitisme possible chez certains crustacés. Bull Biol Fr Belg 64:288-331

Rockey DD, Fryer JL, Rohovec JS (1988) Separation and in vivo analysis of two extracellular proteases and the T-hemolysin from Aeromonas salmonicida. Dis Aquat Org 5:197-204

Sambrook J, Fritsch EF, Maniatis T (1989) Molecular cloning: a laboratory manual, 2nd edn. Cold Spring Harbor Laboratory (CSH), Cold Spring Harbor, NY

Sarath G, De la Motte RS, Wagner FW (1989) Protease assay methods. In: Benyon RJ, Bond JS (eds) Proteolytic enzymes: a practical approach, Vol 3. IRL Press, Oxford

Schulte W, Scholze H (1989) Action of major protease from Entamoeba histolytica on proteins of the extracellular matrix. J Protozool 36:538-543

Small HJ, Neil DM, Taylor AC, Batman K, Coombs GH (2005) A parasitic scuticociliate infection in the Norway lobster (Nephrops norvegicus). J Invertebr Pathol 90:108-117

Söderhäll K, Unestam T (1975) Properties of extracellular enzymes from Aphanomyces astaci and their relevance in the penetration process of crayfish cuticle. Physiol Plant 35:140-146

Sparks AK, Hibbits J, Fegley J (1982) Observations on the histopathology of a systemic ciliate (Paranophrys sp.?) disease in the Dungeness crab, Cancer magister. J Invertebr Pathol 39:219-228

Straus JW, Migaki G, Finch MT (1992) Assessment of proteolytic enzymes in Tetrahymena thermophila. J Protozool 39:655-662

Tiedtke A, Rasmussen L (1988) Lysosomal enzymes in extracellular digestion in the unicellular eukaryote Tetrahymena. J Cell Physiol 136:554-556

Zuo X, Woo PTK (1998) In vitro secretion of the metalloprotease by the pathogenic haemoflagellate Cryptobia salmositica Katz, 1951 and stimulation of the protease production by collagen. J Fish Dis 21:249-255

Zuo X, Woo PTK (2000) In vitro haemolysis of piscine erythrocytes by purified metalloprotease from the pathogenic haemoflagellate Cryptobia salmositica Katz. J Fish Dis 23: $227-230$ 